NBER WORKING PAPER SERIES

\title{
INSTITUTIONAL TAX CLIENTELES AND PAYOUT POLICY
}

\author{
Mihir A. Desai \\ Li Jin \\ Working Paper 13283 \\ http://www.nber.org/papers/w13283
NATIONAL BUREAU OF ECONOMIC RESEARCH
1050 Massachusetts Avenue
Cambridge, MA 02138
July 2007

The authors thank seminar participants at University of California at San Diego, Harvard University, Hong Kong Chinese University and New York University for helpful comments on an earlier draft, and the Division of Research at Harvard Business School for financial support. The views expressed herein are those of the author(s) and do not necessarily reflect the views of the National Bureau of Economic Research.

(C) 2007 by Mihir A. Desai and Li Jin. All rights reserved. Short sections of text, not to exceed two paragraphs, may be quoted without explicit permission provided that full credit, including $@$ notice, is given to the source. 
Institutional Tax Clienteles and Payout Policy

Mihir A. Desai and Li Jin

NBER Working Paper No. 13283

July 2007

JEL No. G32,H24

\author{
Mihir A. Desai \\ Graduate School of Business Administration \\ Harvard University \\ Soldiers Field \\ Boston, MA 02163 \\ and NBER \\ mdesai@hbs.edu \\ Li Jin \\ Harvard University \\ Finance Unit \\ Boston, MA 02163 \\ ljin@hbs.edu
}

ABSTRACT

This paper employs heterogeneity in institutional shareholder tax characteristics to identify the relationship between firm payout policy and tax incentives. Analysis of a panel of firms matched with the tax characteristics of the clients of their institutional shareholders indicates that "dividend-averse" institutions are significantly less likely to hold shares in firms with larger dividend payouts. This relationship between the tax preferences of institutional shareholders and firm payout policy could reflect dividend-averse institutions gravitating to low dividend paying firms or managers adapting their payout policies to the interests of their institutional shareholders. Evidence is provided that both effects are operative. Instrumental variables analysis indicates that plausibly exogenous changes in payout policy result in shifting institutional ownership patterns. Similarly, exogenous changes in the tax code indicate that as the tax cost of paying dividends changes, managers alter their dividend policy to serve their institutional shareholders. 


\section{Introduction}

The tax disadvantage associated with dividend payments has generated numerous theories seeking to explain why firms choose to pay dividends. Given the abundance of theories prompted by the tax disincentive of dividend payments, it is surprising that identifying the role of tax incentives in determining payout policy has proven remarkably difficult. In part, this difficulty reflects the relative absence of variation in tax incentives across time. As a consequence, existing studies of the effects of taxation on dividend payouts, such as Poterba (2004), employ economy-wide data over long time-series to test for the effects of dividend taxes on payout policies.

This paper employs heterogeneity in institutional shareholder tax characteristics to identify the relationship between firm payout policy and tax incentives. Institutional shareholders vary in their tax preferences and firms, in turn, vary in the degree to which they feature institutional shareholder bases that are averse to dividends. By integrating information on the institutional shareholder bases of firms with their dividend behavior, it is possible to analyze the degree to which the tax-based preferences of shareholders are associated with dividend payment behavior by firms. Emphasizing heterogeneity in tax preferences within the class of institutional investors affords the opportunity to identify tax effects more cleanly relative to studies that employ the distinction between individuals and institutions and their presumed tax preferences.

Across a variety of measures of the propensity of firms to pay dividends, the evidence indicates that there is a strong association between the composition of institutional shareholders by their tax preference and dividend payment behavior. This relationship is robust to the inclusion of a variety of controls that have been shown to be associated with dividend paying behavior. Tax clientele effects appear to be strongly present amongst institutional shareholders.

Such an association is consistent with two alternative explanations. First, institutional shareholders may be sorting themselves across firms based on their dividend policies. Alternatively, the tax-based preferences of firm shareholders may be shaping the dividend policy of firms. In order to consider the degree to which either "investor 
sorting" or "tax-based payout policy" is operative, plausibly exogenous variation in dividend policies or the tax-preferences of shareholders is required.

In order to investigate the sorting hypothesis, instrumental variables regressions are employed where a first stage regression predicts dividend payments based on firm operating characteristics. These operating characteristics are plausibly unrelated to the degree to which taxable or non-taxable institutions are shareholders in firms. Secondstage regressions that employ these predicted dividend payments indicate that the composition of institutional shareholders for a firm responds to exogenous variation in dividend changes. Institutional shareholders appear to sort on the basis of dividend policy.

In order to investigate the relevance of the alternative hypothesis that firms are tailoring dividend policies to the preferences of institutional shareholders, the analysis employs exogenous variation in the tax price of dividends relative to capital gains. This variation, created by legislated tax changes over the last two decades, is plausibly unrelated to preexisting dividend policies. Interactions of lagged changes in this tax price with the share of dividend-averse institutional shareholders are strongly associated with changes in dividend policy. Managers appear to alter dividend policy in response to the tax-based preferences of their institutional shareholders.

The rest of the paper proceeds as follows. Section 2 provides a review of the extensive literatures related to our paper. Section 3 describes the data with particular emphasis on the classification of institutions' dividend preference and the empirical specifications. Section 4 presents the results and section 5 concludes.

\section{2. $\quad$ Related Literature}

This paper relates to two expansive literatures. The first literature examines the relationship between clientele effects, institutional shareholders and dividend policy. Beginning with Elton and Gruber (1970), much of this literature examines market reactions to dividends to establish the role of dividend tax clienteles. ${ }^{1}$ Such clientele effects could arise from non-tax considerations including informational advantages,

\footnotetext{
${ }^{1}$ See Allen and Michaely (2003) for a review of this evidence.
} 
distinct investment styles, or monitoring ability. Institutions may be better informed and this informational advantage could be manifest in differing attitudes toward payout policy. Indeed, Amihud and Li (2006) study the relation between price reaction to dividend announcements and institutional holdings, and find evidence that institutions are more informed. Hotchkiss and Lawrence (2003) report that institutions seem to have distinct investment styles based on dividend yields but they do not find evidence of taxbased clienteles. Michaely, Thaler, and Womack (1995) fail to find a significant change in institutional ownership after dividend omissions. Del Guercio (1996) examines the role of dividends in the portfolio selection of banks and mutual funds, and finds that dividend yield has no power in explaining the portfolio choice of these institutions. Her evidence suggests that the prudent-man rule has an important role, but that dividends do not play a major role in institutional investor portfolio decision. On the other hand, Dhaliwal, Erickson, and Trezevant (1999) provide empirical evidence that after dividend initiation, the firms' institutional investor clientele changes based on their tax preferences, with a surge of ownership by tax-exempt/tax-deferred and corporate investors.

Grinstein and Michaely (GM) (2005) provide a comprehensive investigation of the relationship between institutional ownership and payout policy. GM consider a variety of factors that could affect payout policy, including institutional monitoring (along the lines of Allen, Bernado and Welch 2000), free-cash flow problems as in Jensen (1986), taxation, regulatory changes and adverse selection, in order to establish whether payout policy affects the willingness of institutions to invest in stocks and whether a concentration of institutional holders, in turn, affects future payout policy. While their results are affirmative on the role of many factors, they do not find meaningful tax-based preferences, consistent with the survey results in Brav, Campbell, Harvey, and Michaely (2005) that institutional investors as a whole do not show a clear preference for dividend over repurchase. However, GM conclude that it is "possible that there is too much heterogeneity among institutions to capture this effect when we are looking at institutions as a whole or even at subgroups of institutions (such as pension funds)."

Our work builds on the foundation laid by GM and others by using heterogeneity of tax preferences within the class of institutional investors to investigate the role of taxbased clienteles. By comparing different types of institutions, rather than the typical 
individual vs. institution comparison, we are able to isolate tax explanations relative to a variety of other explanations, including differential monitoring capacities and sophistication. Institutional investors are also more likely to be pivotal and, indeed, Graham and Harvey (2001) provide survey results that firms do react to their institutional investors.

Focusing on institutions and on the impact of tax on payout policy also enables us to significantly sharpen our measures of tax preference and payout policy. Depending on their tax preference, institutions can be classified into three groups: the pass-through institutions for taxable investors prefer capital gains over dividend, the pass-through institutions for tax-exempt investors are neutral, and the corporations prefer dividends over capital gains, as dividends and capital gains are treated differentially. ${ }^{2}$ Using a new database containing more precise classifications of institutions on the tax front, we more precisely estimate the tax preference of a firm's aggregate institutional investors. We also refine the payout policy measure to better reflect the tax preference question. In particular, since our focus is not on the free cash flow problem, we are less interested in testing the overall level of payout, but rather the division between dividend and repurchase. This contrasts with GM, who do not directly study the composition of the total payout. ${ }^{3}$

Parallel to the efforts focusing on clientele effects for institutional investors, Scholz (1992) and Graham and Kumar (2006) examine portfolio decisions of retail investors to provide more direct evidence of the degree to which tax characteristics of investors are associated with their portfolio holdings. This paper provides an institutional analog to these papers by exploring heterogeneity within institutional shareholders to see if institutional shareholdings feature similar clientele effects.

\footnotetext{
${ }^{2}$ See Desai and Gentry (2004) for a discussion of corporate responsiveness to corporate capital gains treatment and Barclay, Holderness and Sheehan (2007) for an investigation of corporate preferences for dividends.

${ }^{3}$ In a related vein, Jain (1999) reports that institutions prefer to invest in low-dividend-yield stocks, whereas individual investors prefer higher dividend-yield stocks, inconsistent with a tax-based dividend clientele hypothesis which assumes institutions to be tax-advantaged. Strickland (1996) comes closest to our efforts by finding that taxable institutional owners prefer low-dividend yield stocks but also reports that tax-exempt investors do not appear to show a preference for either high or low-yield stocks.
} 
This paper also contributes to the sizable literature that examines if dividend tax changes influence dividend policy. Poterba $(1987,2004)$ employs time-series variation and economy-wide dividend payments while more recent studies - including Blouin, Raedy and Shackelford (2003), Brown, Liang and Weisbenner (2007) and Chetty and Saez (2005) - all examine how firms responded to the 2003 dividend tax cuts. These studies typically employ managerial shareholdings and institutional shareholdings to sharpen their hypothesis tests of the effects of the recent dividend tax cut. Bernheim and Wantz (1995) employs the time-series variation emphasized by Poterba to test the motivations for paying dividends while Perez-Gonzales (2003) uses this same variation to investigate if large individual shareholders shape the dividend policies of the firms they own. To our knowledge, this paper is the first one to employ variation in tax-preferences across institutional shareholders to isolate the degree to which dividend policy at the firm level is related to the tax preferences of shareholders across a broader period.

\section{Data and methodology}

In order to analyze the relationship between tax preferences of institutional shareholders and dividend policy, the paper integrates detailed data on the characteristics of institutional shareholders with firm data on payout policy and operating characteristics.

\subsection{Identifying the tax preferences of a firm's institutional shareholders}

Previous work has measured the tax preferences of shareholders as a function of whether their shareholders were largely institutions or retail investors. More recently, studies of the recent tax cut have classified institutions somewhat more finely but without reference to the tax preferences of the clients that these institutions serve. In order to consider the degree to which firms are held by dividend-averse investors, we begin by supplementing data on institutional investor holdings with data on the tax preferences of the clients they serve.

The institutional shareholder data used in this study are from the Spectrum $13 \mathrm{~F}$ institutional investor holdings database. Investment managers who exercise investment discretion over \$100 million or more in Section 13F securities must report to the SEC on Form 13F holdings of more than 10,000 shares or investments valued in excess of $\$ 200,000$. Data are available from 1980 to 2002 . However, a number of institutions are 
improperly classified in 1998 and beyond. As a result, our analysis is limited to the period from 1980 to 1997 . To make the analysis based on institutional investors meaningful, we further limit the sample to those firms where at least $10 \%$ of the common shares outstanding are held by institutional investors that we could identify in the $13 \mathrm{~F}$ data.

Spectrum reports five types of institutional investors: i) bank trust departments, the clients of which can be either taxable or tax-exempt; ii) insurance companies, which are taxable overall but could have tax-exempt accounts for clients; iii) investment companies (open-end or closed-end mutual funds), the clients of which can be either taxable or tax-exempt; iv) independent investment advisors, whose clients can be either tax-sensitive or non-tax-sensitive; and v) "others" such as foundations, ESOPs, university endowments, and internally managed private and public pension funds, many of which are tax-exempt.

In order to calculate the share of institutional investors that are dividend-averse, we follow the procedure outlined below. Of all the institutional investors, banks and investment companies (mutual funds) are not classified as either dividend-averse or nondividend-averse from this study, as no concrete information about their taxable investor bases can be obtained. ${ }^{4}$ Instead, we assume that these two categories have the same ratio of dividend-averse shareholders as imputed from the remaining institutional shareholders. Insurance companies are uniformly treated as not being dividend-averse as they are in the corporate form and thus enjoy the dividend reduction. ${ }^{5}$ Finally, investment advisors and the "other" category are classified on the basis of their client characteristics. For these purposes, institutional holdings data are supplemented with Investment Adviser Public

\footnotetext{
${ }^{4}$ Another important consideration is that banks and mutual fund families typically consist of many separate accounts or funds. To the extent that these accounts/funds don't have the same level of tax-savvyness and that $13 \mathrm{~F}$ reports only aggregate holdings data, documenting the existence of tax-sensitive trading using aggregate data might be expected to be more difficult. The multiple account problems might still exist in other types of institutions, but would be much less severe.

${ }^{5}$ There are some caveats. Life insurance and property insurance companies have different tax treatments and could have different reactions to capital gains tax overhang. Moreover, insurance companies invest in their own accounts large amounts of money on which they pay taxes, but they also invest on behalf of their clients through potentially tax-advantaged accounts. The $13 \mathrm{~F}$ data does not allow us to differentiate on these. To the extent that this could generate noise, as a robustness check, we re-do the tests reported in this paper assuming insurance companies having the same tax characteristics as the mutual funds. The results are not affected qualitatively.
} 
Disclosure (IAPD) data obtained from the SEC. IAPD data contain investment advisors' self-reported client bases broken down into ten categories: Individuals (other than high net worth individuals); high net worth individuals; banking or thrift institutions; investment companies (including mutual funds); pension and profit sharing plans (other than plan participants); other pooled investment vehicles (mostly hedge funds); charitable organizations; corporations or other businesses not listed above; state or municipal government entities; and "others" such as non-U.S. government entities. Investment advisors are required to report the percentage of business represented by each client category.

Investment advisors can have different preferences over dividend versus capital gains, depending on the nature of the clients they serve. We classify an investment advisor as dividend-averse if (1) there exists tax sensitive investors capable of exerting pressure on managers, or (2) managers of the investment advisor might for personal reasons care about the tax consequences of the portfolios they manage. Among institutional investors who, a priori, might be expected to prefer capital gains over dividends are investment managers for high net worth individuals and hedge funds. The interests of the former are served by their relatively small number, which facilitates communication and collaboration with and, ultimately, monitoring and collective discipline of fund managers. Managers of hedge funds, for incentive reasons, are typically required to invest a significant portion of their personal wealth in the funds they manage and so are likely to care about tax consequences of dividend versus capital gains for personal reasons. ${ }^{6}$

The profiling information from IAPD is used to distinguish independent investment advisors who serve primarily tax-sensitive clients from those who serve primarily non-tax-sensitive clients. We classify as tax-sensitive those independent investment advisors whose clientele consists primarily ( $\geq 50 \%$ ) of high net worth

\footnotetext{
${ }^{6}$ Many of the industry experts we talked to indicated that tax is an important consideration for some institutions. For example, Morgan White, managing director of Woodside Asset Management, Inc., which manages money for high net worth individuals and families, stated in an e-mail correspondence dated November 11, 2003: "Indeed, we do pay close attention to taxes when making selling decisions." He went on to explain that they strictly follow "Highest-In, First-Out" selling of multiple lots to minimize tax liability, postpone realization of gains, and expedite realization of losses to offset gains realized in the same year.
} 
individuals and hedge funds. ${ }^{7}$ Institutions are classified as tax-exempt and thus nondividend-averse if pension funds, state and local governments, and charitable organizations account for more than $50 \%$ of their clientele. This classification of taxsensitive and non-tax-sensitive institutions is fairly conservative. As there are cases where clients cannot be clearly identified as either dividend-averse or non-dividendaverse, these investment advisors are not classified. For institutions categorized in $13 \mathrm{~F}$ data as "other" we conduct word searches for "pension," "endowment," "foundation," and variations thereof and identify as non-dividend-averse any for which these words come up in their names. Finally, for each stock in each period, we calculate the proportion of dividend-averse investors as the ratio of identifiable dividend-averse institutional holdings to the sum of identifiable dividend-averse and non-dividend-averse institutional holdings. ${ }^{8}$ Figure 1 plots the mean and median of the proportion of dividend-averse institutions among all identifiable institutions, during the period of 1981 to 1997. There is considerable time-series variation of both the mean and the median of the dividend-averse institution proportion, and at any time, there are a substantial proportion of a typical firm's institutional investors that are dividend-averse: the mean and the median are both within the range of $25 \%$ to $50 \%$ during this time period and there does not appear to be a significant time trend to the series.

\subsection{Measuring Payout Policy}

Earlier papers have focused on dividend yield to study the dividend policy. Recent papers, such as Grinstein and Michaely (2005), Allen and Michaely (2006), Grullon and Michaely (2002) and Blouin and Nondorf (2004) pointed out that such measures provide an incomplete picture. If a firm increases dividend payment and share repurchase expenditures proportionally, it is difficult to conclude that the dividend policy is more (or less) tilted towards dividends. Rather, such increase is a demonstration of

\footnotetext{
${ }^{7}$ We also include investment advisors who do not file the IAPD forms but are identified in the hedge funds section of the Money Manager Directory. As reported by Brunnermeier and Nagel (2004), only institutions that conduct non-hedge fund businesses such as advising mutual funds and pension plans are expected to file for the IAPD disclosure. That they are classified as hedge funds in the Money Manager Directory and not listed on the IAPD form indicates that the majority of their business is in hedge funds.

${ }^{8}$ This calculation implicitly assumes that the unidentified portion of the institutional investors have the same proportional distribution as the identified portion of the investors. Such assumption clearly is not precise, but we are not aware of any systematic bias, thus the approximation might add noise, but not bias, to our empirical work.
} 
overall increase in payout. Accordingly, we will be focusing on the dividend payout ratio as defined below to better capture the relative importance of dividends as a form of payout rather than changes in the overall amount of firm payout.

In order to measure repurchases, we follow the definition in Grullon and Michaely (2002) as the expenditures on the purchase of common and preferred stocks (Compustat industrial annual data item \#115) minus any reduction in the value (redemption value) of the net number of preferred shares outstanding (Compustat industrial annual data item \#56). We define common dividends as the total dollar dividends declared on the common stock during the firm's applicable fiscal year (Compustat industrial annual data item \#21). The "dividend payout ratio" is defined as the ratio of dividends to the sum of dividends and repurchases. By construction, our measure of the proportion of dividend payment among total payout is only well-defined for firms that either pay dividend or do stock repurchase during a year. Of an initial sample of 113,350 firm-year observations for which we have other data, 36,708 are eliminated as firms don't either pay dividend or do repurchase during that year.

Our measure of firm dividend policy may have a bias. Firms omitted because they neither pay dividend nor repurchase stock in a year might be more likely to prefer capital gains to dividends. Compared to paying dividend or repurchase, paying nothing leads to increase in the retained earnings at the firm, thus the share price will be higher. The practice of retaining earnings in the firm thus creates capital gains rather than dividend on the stock, therefore we might want to treat it as functionally equivalent to repurchase. Our approach excludes these observations from our analysis, and thus might have some bias. As a robustness check, we conduct tests including the firms with zero payout, but nonetheless have a cash-to-asset ratio of $10 \%$ or higher, and treat them as if they have a dividend/(dividend+repurchase) of zero. We were able to re-classify 14,043 firm-years that way. The results reported in our tables do not change qualitatively when we use this alternative measure of dividend payout ratio.

\subsection{Empirical Methodology}

These measures of the tax-based aversion to dividends of institutional shareholders and dividend payout ratios are supplemented with various additional 
explanatory variables. We follow convention in constructing measures such as the levels of cash holdings, return on assets, market capitalization, earnings, ratio of capital expenditure to assets, and leverage. ${ }^{9}$ Of particular note is the measure of ROA volatility. Following Jagannathan, Stephens and Weisbach (2000), ROA volatility is measured as the standard deviation of the ratio of operating income to total assets measured over the 5 -year period from year -4 through 0 for a given year. Summary statistics for the variables described above are provided in Table 1.

The analysis begins in Table 2 by investigating the basic association between dividend payout ratios and the dividend aversion of institutional shareholders. This analysis also investigates the relevance of industry controls at the two-digit SIC level and controls for other determinants of dividend policy that have been discussed in the literature for this basic association. The regressions all have year fixed effects and standard errors are clustered at the industry level. In addition, the Fama-MacBeth regression methodology developed in Fama and MacBeth (1973) is also employed to address potential cross-correlation in the data. The analysis in Table 3 considers if samples where institutions are more likely to be pivotal and where their tax preferences are more readily identifiable provide consistent results. Tables 4 and 5 provide an instrumental variables analysis where exogenous changes in dividend payouts, as predicted by cash holdings and ROA volatility, are linked to changes in the institutional shareholder bases of firms. Finally, Table 6 considers the role of changes in tax policy on dividend payouts by examining if firm payout policy responses to tax changes are linked to the degree to which their shareholders are dividend-averse.

\section{Results}

\subsection{Payout policy and institutional shareholder dividend aversion}

\footnotetext{
${ }^{9}$ Cash holdings is defined as the ratio of cash and marketable securities (Compustat Item \#1) to total assets (Compustat Item \#6). Return on assets is the ratio of operating income (Compustat Item \#13) to total assets (Compustat Item \#6). Market capitalization is the product of common shares outstanding (Compustat Item \#24) and year-end price (Compustat Item \#25). Earnings is defined following the standard accounting literature, for example, Rosett (2001), as Earnings After Interest and Tax (Item \#18). Ratio of capital expenditure to assets is defined as the ratio of capital expenditures (Compustat Item \#128) to total assets (Compustat Item \#6). Leverage is defined as the ratio of the book value of debt to total assets, where the book value of debt is measured as book value assets less book value of equity (Compustat Item \#6Compustate \#216), and total assets is measured by Compustat Item \#6.
} 
Prior to investigating the relationship between institutional shareholder dividend aversion and payout policy in a regression framework, it is useful to investigate if a relationship is apparent in the raw data. Figure 2 provides such an effort. For each year in the sample, the sample of firms is partitioned into four quartiles depending on the proportion of their identifiable institutional investors that are dividend-averse.

Observations are then aggregated across years within these quartiles and a mean payout ratio is calculated for each quartile. By construction, there are equal numbers of firms in each quartile. The figure provides the mean dividend payout ratio against the quartiles' average (mean) level of the proportion of dividend-averse institutional investors. As is clear from Figure 2, there is a negative relationship between the proportion of dividendaverse institutions in a firm and the dividend payout ratio of the firm in the raw data. The highest dividend-averse institutional investor concentration corresponds to an average dividend payout ratio of $73 \%$, whereas the lowest concentration corresponds to an average dividend payout ratio of $58 \%$.

The specification in column 1 of Table 2 formalizes this analysis in a regression framework. The negative and highly significant coefficient indicates that changing the share of dividend-averse institutional shareholders from 0 to 1 would be associated with a reduction in the dividend payout ratio of 11 percent. The inclusion of additional controls in column 2 - ROA, ROA volatility, earnings, market value, the ratio of capital expenditure to assets, the market to book ratio, and leverage - does not alter this basic finding. The specifications in columns 3 and 4 of Table 2 add industry controls and the association between institutional shareholdings and dividend payout forms remains consistent.

To be consistent with a large body of literature in finance we also use the FamaMacBeth methodology to compute robust standard errors on the coefficient estimates. The Fama-MacBeth methodology is a convenient and conservative way to account for potential cross-correlations in residuals. As reported by Fama and French (2002), the Fama-MacBeth standard errors can potentially be two to five times the OLS standard errors from pooled panel data regressions that ignore residual cross-correlations. Specifically, we first run cross-sectional regressions for each year separately, controlling for fixed effects at the industry level, and report the time-series averages of the 
coefficient estimates using the time-series standard errors of the average slopes to draw inferences. Because the Fama-MacBeth procedure does not take into account residual autocorrelations, it is further corrected by following the procedure in Pontiff (1996) to adjust the time-series standard deviations to allow for a first order autocorrelation in the coefficient estimates. Columns 5 through 8 of Table 2 provide the results using this Fama-MacBeth procedure and the results of the OLS specifications are confirmed.

In order to investigate the robustness of this association between dividend-averse institutional shareholders and payout policy, we also investigated if different cutoffs for the level of institutional investors holdings and the proportion of institutional holdings that can be identifiable changed the basic results. To make sure that the institutional investors are the dominant shareholders in a firm, we repeated the specifications of Table 2 but required that at least $50 \%$ of the shares outstanding (rather than 10\%) are held by institutional investors. In a related vein, to make sure that our dividend-averse institutional classification does not over-represent the true distribution of institutional types, we repeated the test requiring that at least $25 \%$ of the institutional holdings are identifiable (previously there was no cutoff)) as either the dividend-averse or nondividend-averse institutional holdings. Table 3 reports the results of the robustness checks where we require both $50 \%$ institutional ownership of firms and that $25 \%$ of those institutional holdings be identifiable. These results, on this significantly reduced sample size, are confirmatory of the patterns from Table 2. It is interesting to note that the coefficient estimates are considerably higher - almost three times higher than the corresponding specifications in Table 2. The coefficient estimates from column 4 of Table 3 indicates that changing the share of dividend-averse institutional shareholders from 0 to 1 is associated with a decreased dividend payout ratio of 33 percent. Given that measurement issues are more limited in this sample and that institutions are more likely to be pivotal, these results are reassuringly significantly larger than those in Table 2 .

\subsection{Do dividend changes drive changes in ownership patterns?}

This negative association between the concentration of dividend-averse institutions and the dividend payout ratio provides direct evidence of clientele effects amongst institutions. This evidence, however, does not indicate if institutional 
shareholders are sorting or if tax-based preferences of shareholders are dictating payout policy. In order to analyze if institutional shareholders are sorting across firms, Tables 4 and 5 consider how plausibly exogenous changes in dividend policy shift shareholding patterns.

In order to test whether exogenous changes in dividend payout ratios attract dividend-averse institutional investors, we regress the proportion of dividend-averse institutional investors on predicted dividend payout ratios, generated by a first stage regression using cash levels and ROA volatility as independent variables ${ }^{10}$. The premise of these specifications is that these variables are associated with changes in payout policy but are not directly related to the degree to which dividend-averse institutional shareholders are drawn to firms. It is important to note that this is a setting where it is particularly useful to be focused on the share of institutional shareholders that are dividend averse rather than just the share of institutional shareholder per se.

The results of the first stage regressions are provided in Table 4. When we regress the dividend payout ratio on the ratio of cash to assets and ROA volatility, we find that the coefficient on cash is negative and statistically significant, indicating that firms with more cash pay out disproportionately more through repurchases rather than dividends. The coefficient on ROA volatility is also negative, indicating that firms with more volatile earnings pay out disproportionately more through repurchases. The pattern is robust whether we do the univariate or multivariate regressions. The predicted values from the regressions with both instruments are employed in the second stage regressions discussed below.

The second stage results are provided in Table 5. The coefficients on the predicted values of the dividend payout ratio are negative and highly significant. These results are fairly stable across specifications that include industry controls and additional controls for other determinants of institutional shareholding patterns. In the specification in column four, the coefficient estimate indicates that a change in payout policy from no

\footnotetext{
${ }^{10}$ Jagannathan, Stephens, and Weisbach (2000) and Guay and Harford (2000) find that firms that pay dividends have more stable earnings than do firms that use share repurchases. They conclude that share repurchases are used to pay out extraordinary transitory earnings and dividends are used to pay out permanent earnings.
} 
dividends to all dividends would result in a 20 percent reduction in the degree to which shareholders are dividend-averse. These results are robust to the use of the FamaMacbeth procedure discussed above as indicated by the results in columns 5 through 8 . In short, changes in dividend that are plausibly unrelated to the composition of taxable preferences of investors are associated with changes in the institutional investor composition. Institutional investors appear to sort on the tax consequences of firm payout policy.

\subsection{Do the preferences of institutional shareholders drive dividend policy?}

While the results of Tables 4 and 5 indicate that institutional investors are sorting across firms, it is possible that the results in Tables 2 and 3 could also be explained by managers responding to the tax-based preferences of their institutional shareholders through changed payout policy. In order to investigate if such a mechanism is operative, we investigate if dividend policy responds to arguably exogenous changes in firm institutional investors' tax preference. These changes are identified as those arising from changes in the relative cost of dividends to capital gains and the proportion of firm institutional investors that are dividend-averse.

To measure the time-series change in the investor preferences for dividends relative to capital gains, we follow Poterba $(1987,2004)$. Poterba defines the tax preference parameter $(\theta)$ as the after-tax value of a dollar of dividends, relative to the

after-tax value of a dollar of capital gains. Specifically, if $\tau_{\text {div }}$ and $\tau_{\text {cg }}$ denote the marginal tax rates on dividends and long-term capital gains, respectively, then the dividend tax preference parameter is given by $\theta_{t}=\left(1-\tau_{d i v, t}\right) /\left(1-\tau_{c g, t}\right)$.

We could similarly define a tax preference parameter for corporate investors. As Poterba (2004) and Barclay, Holderness, and Sheehan (2007) show, there is little evidence that corporate investors affect and/or react to firm dividend policy. One possible reason is that corporate investors are investing for strategic reasons, and dividend policy is at best a second order consideration for these investors. For simplicity, we exclude the corporate investor tax preference parameter in our specification. In additional (unreported) tests including these parameters, they are not significant. Furthermore, no 
other parameter's significance level is materially affected by the inclusion of the corporate tax preference parameter.

Poterba (2004) uses aggregate data to study how the time-series change in the weighted average tax preference parameter affects aggregate dividend payments. He estimates a model similar to Lintner's (1956) partial adjustment model of corporate dividends. The annual change in real dividends, $\Delta \ln D_{t}$, is modeled as a function of the change in corporate profits ( $\Delta \ln$ Profit $t)$ and the change in the relative tax burden on dividends versus capital gains $\left(\Delta \ln \theta_{t}\right)$. In addition, changes in dividends are also a function of lagged levels of profits, dividends, and the relative tax burden. The specification he employs is:

$$
\begin{aligned}
& \Delta \ln D_{t}=\beta_{0}+\beta_{1}\left(\Delta \ln \text { Profit }_{t}\right)+\beta_{2}\left(\Delta \ln \theta_{t}\right)+\beta_{3}\left(\ln D_{t-1}\right)+ \\
& \beta_{4}\left(\ln \text { Profit }_{t-1}\right)+\beta_{5}\left(\ln \theta_{t-1}\right)+\varepsilon_{t}
\end{aligned}
$$

As explained in Poterba (2004), the estimated long-run elasticity of dividend payout with respect to the weighted-average tax price is $-\beta_{5} / \beta_{3}$. Using time-series analysis of economy-wide dividend payments, Poterba estimates that the long-run elasticity of dividend payout with respect to the weighted-average tax price is 3.9 to 5.1, depending on how exactly profit is accounted for. That suggests that a one percentage increase in the tax preference parameter will increase dividend payouts by $3.9 \%$ (or $5.09 \%$ ) in the long run.

While Poterba's evidence is at the macro level, we employ our measure of a firm's institutional investor distribution (between dividend-averse and non-dividendaverse investors) to further test whether at firm level the tax preference change, combined with the change in the proportion of dividend-averse institutional investors, are likely affecting firms' dividend policy. To do that, we interact our measure of the proportion of the dividend-averse institutional investors with the Poterba tax preference parameter, to form a measure of overall "representative investor tax preference", as the weighted average value of dividend. In particular, we define the representative investor tax preference as $T=\theta \times$ proportion_dividend_averse $+1 \times(1-$ proportion_dividend_averse $)$ 
If firms indeed react to the tax consequence of its representative institutional investor, then, as the "representative investor tax preference" increases, dividend payment will increase. Specifically, the regression specification we employ is:

$$
\begin{aligned}
& \Delta \ln D_{i t}=\beta_{0}+\beta_{1}(\Delta \ln \text { salest })+\beta_{2}\left(\Delta \ln T_{i t}\right)+\beta_{3}\left(\ln D_{t-1}\right)+\beta 4(\ln \text { sales } t-1)+ \\
& \beta_{5}\left(\ln T_{t-1}\right)+\beta_{6}\left(\ln \theta_{t-1}\right)+\varepsilon_{t}
\end{aligned}
$$

where $\mathrm{D}_{\mathrm{it}}$ is the dividend payout ratio for a firm-year observation.

Prior to discussing the results, several points should be noted. In the regression specification, we have changed the household tax parameter $\left(\theta_{t}\right)$ to the weighted average tax preference parameter $\left(T_{i, t}\right)$, so as to generate both time series and cross-sectional variation in the tax environment of firms' representative institutional investors. We have changed the $\ln$ of profit to $\ln$ of sales revenue, as profit can be negative for individual firms (but not for the aggregate data that Poterba employs). The use of sales in place of the (sometimes negative) profit is standard, as in papers such as Perez-Gonzalez (2003) and Grinstein and Michaely (2005). In addition, we can no longer use Fama-MacBeth, because we are using the time series variation of the relative price of dividend to capital gains (the Poterba theta). We instead add the year fixed effect, and industry fixed effect (because dividend policy is likely correlated with industry characteristics), and firm level controls that are used by other studies, such as Perez-Gonzales (2003) and Grinstein and Michaely (2005). We tried the specification with or without controls on market to book ratio, asset growth, beta adjusted excess return of the stock. The main results are not sensitive to these additional controls. As in the Poterba specification, the short-run effect of tax preference change on dividend payout ratio is captured by $\beta_{2}$, whereas the long-run effect is by $-\beta_{5} / \beta_{3}$.

Results for this specification are reported in Table 6. Columns 1 and 3 of Table 6 do not include the lagged value of theta and columns 3 and 4 add industry controls. The short run elasticity of dividend policy to tax preference change is very weak and statistically insignificant corroborating the findings of Poterba. Longer run, there is a significant response to the tax preference change of investors. Using the calculation similar to Poterba (2004), the long run elasticity of dividend payout ratio to the change in representative investor dividend valuation is 2.11 in the first column and 1.77 in the third. 
These results hold even after directly controlling for the time series variation of the tax preference parameter $\left(\theta_{t}\right)$, as reported in columns 2 and $4 .{ }^{11}$ Firms respond to the tax preferences of their institutional investors, at least in the long run.

\section{Conclusion}

Analyses that consider heterogeneous groups of investors such as institutions homogenously risk conflating tax attributes with other unique aspects of institutions as shareholders. Similarly, analyses that emphasize dividends without considering the tradeoffs relative to repurchases may fail to capture heterogeneity in payout policy. The analysis in this paper capitalizes on the heterogeneity in payout policy and heterogeneity within the tax preferences of a type of investor to provide direct evidence of the presence of dividend clienteles. These clientele effects are more pronounced in the restricted sample where tax-preferences are more clearly identified and those preferences are more likely to be pivotal. Such clientele effects are consistent with investors sorting to firms with attractive payout policies and with managers altering payout policy in response to shareholder tax-based preferences. These alternative channels are not exclusive and evidence is provided that both are operative.

\footnotetext{
${ }^{11}$ While we report the long-run elasticity in the same fashion as in columns 1 and 3, the estimated long-run elasticity in columns 2 and 4 are less interpretable, given we also directly control for theta.
} 


\section{References}

Allen, Franklin, Antonio E. Bernardo, and Ivo Welch. 2000. A theory of dividends based on tax clienteles. Journal of Finance 55(6): 2499-2536.

Allen, Franklin, and Roni Michaely. 2003. Payout policy.In Handbook of the Economics of Finance: Volume 1A, Corporate Finance, edited by George M Constantinides, Milton Harris, and René M. Stultz, 337-430.Amsterdam: Elsevier North Holland

Amihud, Yakov, and Kefei Li. 2006. The declining information content of dividend announcements and the effect of institutional holdings. Journal of Financial and Quantitative Analysis 41(3): 637-660.

Barclay, Michael J., Clifford G. Holderness, and Dennis P. Sheehan. 2007. Dividends and corporate shareholders. Working paper, University of Rochester, BostonCollege and Pennsylvania State University.

Bernheim, B. Douglas, and Adam Wantz. 1995. A tax-based test of the dividend signaling hypothesis. American Economic Review 85(3): 532-551

Blouin, Jennifer, and Maria E. Nondorf. 2004. Payout policy: A shareholder-level analysis. Working paper, University of Pennsylvania and University of California, Berkeley.

Blouin, Jennifer, Jana S. Raedy, and Douglas A. Shackelford. 2003. Capital gains taxes and equity trading: empirical evidence. Journal of Accounting Research 41(4): 611652.

Brav, Alon, John R. Graham, Campbell R. Harvey, and Roni Michaely. 2005. Payout policy in the 21st century. Journal of Financial Economics 77(3): 483-527.

Brown, Jeffrey R., Nellie Liang, and Scott Weisbenner. 2007. Executive financial incentives and payout policy: firm responses to the 2003 dividend tax cut. Forthcoming in Journal of Finance.

Brunnermeier, Marcus and Stefan Nagel. 2004. Hedge funds and the technology bubble. Journal of Finance 59(5): 2013-2040.

Chetty, Raj, and Emmanuel Saez. 2005. Dividend taxes and corporate behavior: Evidence from the 2003 dividend tax cut, Quarterly Journal of Economics 120 (3): 791-833.

Del Guercio, Diane. 1996. The distorting effect of the prudent-man laws on institutional equity investments. Journal of Financial Economics 40(1): 31-62.

Desai, Mihir, and William Gentry. 2004. The Character and Determinants of Corporate Capital Gains. In Tax Policy and the Economy 18, edited by J. Poterba, 1-36. Cambridge, MA: MIT Press. 
Dhaliwal, Dan, Merle Erickson, and R. Trezevant. 1999. A test of the theory of tax clienteles for dividend policies, National Tax Journal 52: 179-194.

Elton, Edward J., and Martin J. Gruber. 1970. Marginal stockholder tax rates and the clientele effect. Review of Economics and Statistics 52(1): 68-74.

Fama, Eugene F., and Kenneth R. French. 2002. Testing trade-off and pecking order predictions about dividends and debt. Review of Financial Studies 15(1): 1-33.

Fama, Eugene F., and James D. MacBeth. 1973. Risk, return, and equilibrium: Empirical tests, Journal of Political Economy 81(3): 607-636.

Graham, John, and Campbell R. Harvey. 2001. The theory and practice of corporate finance: Evidence from the field. Journal of Financial Economics 60(2/3): 187-243.

Graham, John R., and Alok Kumar. 2006. Do dividend clienteles exist? Evidence on dividend preferences of retail investors. Journal of Finance 61(3): 1305-1336.

Grinstein, Yaniv, and Roni Michaely. 2005. Institutional holdings and payout policy, Journal of Finance 60 (1): 1389-1426.

Grullon, Gustavo, and Roni Michaely. 2002. Dividends, share repurchases, and the substitution hypothesis, Journal of Finance 57(4): 1649-1684.

Grullon, Gustavo, Roni Michaely, and Bhaskaran Swaminathan. 2002. Are dividend changes a sign of firm maturity? Journal of Business 75(3): 387-424.

Guay, Wayne and Harford, Jarrad. 2000. The cash flow permanence and information content of dividend increases vs. repurchases. Journal of Financial Economics 57 (3): $385-415$.

Hotchkiss, Edith S., and Stephen Lawrence. 2003. Empirical evidence on the existence of dividend clienteles. Working Paper, Department of Finance, Boston College, May 2003.

Jagannathan, Murali, Clifford P. Stephens, and Michael S.Weisbach. 2000. Financial flexibility and the choice between dividends and stock repurchases. Journal of Financial Economics 57(3): 355-384.

Jain, Ravi. 1999. Essays on agency costs, dividend policy, and corporate ownership structure. Ph.D. Dissertation, UCLA.

Jensen, Michael C. 1986. Agency costs of free cash flow, corporate finance, and takeovers, American Economic Review 76(2): 323-329. 
Lintner, John. 1956. Distribution of incomes of corporations among dividends, retained earnings, and taxes. American Economic Review 46(2): 97-113.

Michaely, Roni, Richard H. Thaler, and Kent Womack. 1995. Price reactions to dividend initiations and omissions: Overreaction or drift? Journal of Finance 50(2): 573-608.

Perez-Gonzalez, Francisco. 2003. Large shareholders and dividends: Evidence from U.S. tax reforms. Working Paper, Graduate School of Business, Columbia University, January 2003.

Pontiff, Jeffrey. 1996. Costly arbitrage: Evidence from closed-end funds. Quarterly Journal of Economics 111(4): 1135-1151.

Poterba, James. 1987. Tax Policy and Corporate Savings. Brookings Papers on Economic Activity 1987(2): 455-515.

Poterba, James. 2004. Taxation and Corporate Payout Policy. American Economic Review 94(2): 171-175.

Rosett, Joshua G. 2001. Equity Risk and the Labor Stock: The Case of Union Contracts. Journal of Accounting Research 39(2): 337-364.

Scholz, John K. 1992. A direct examination of the dividend clientele hypothesis. Journal of Public Economics 49(3): 261-285.

Strickland, Deon. 1996. Determinants of institutional ownership: Implications for dividend clienteles. Working paper, Ohio State University. 


\section{Figure 1: The Proportion of Dividend-Averse Insitutional}

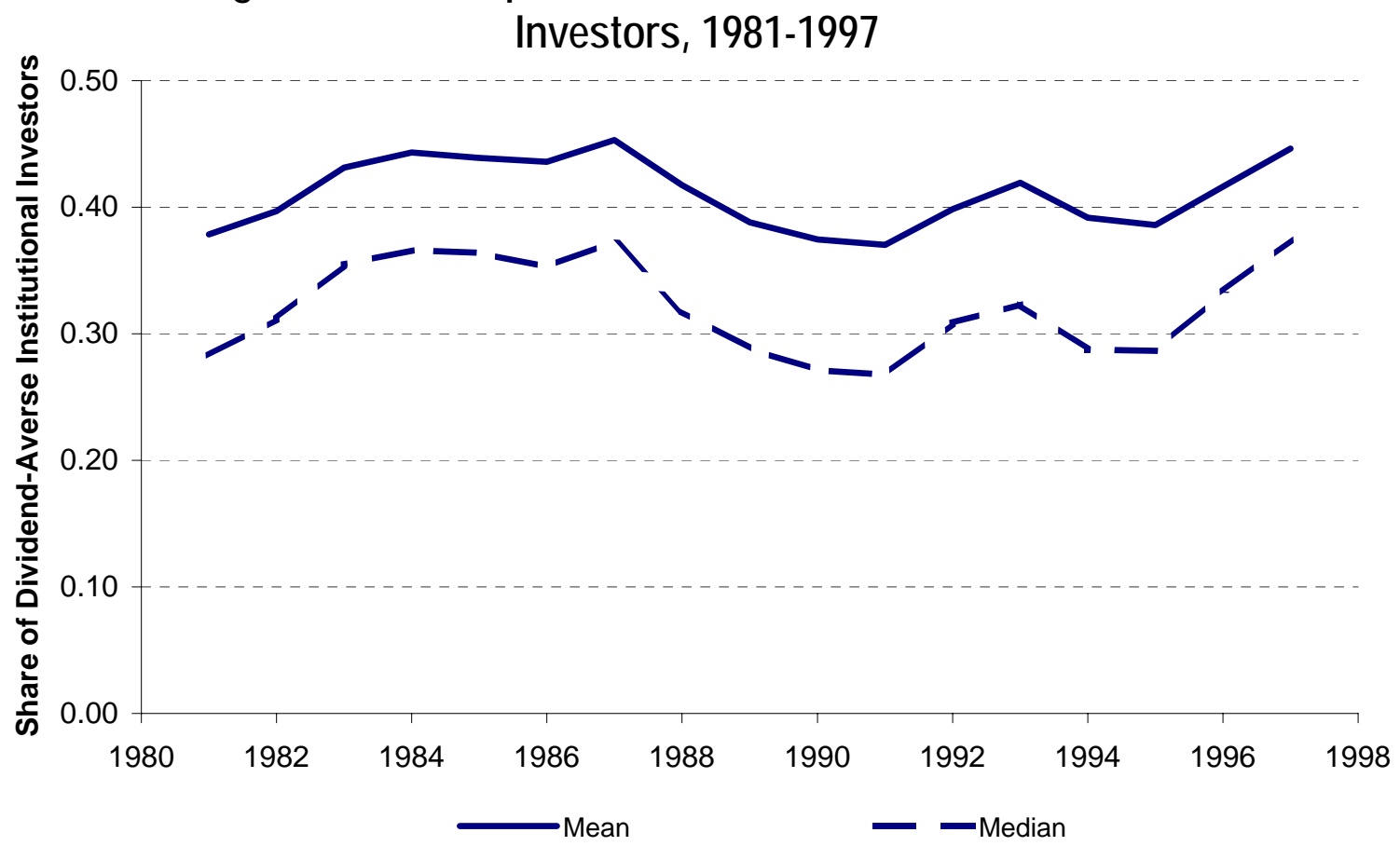

Note: This figure plots the share of dividend-averse institutional investors for companies in the sample in the paper.

\section{Figure 2: Dividend payout ratios across quartiles of dividend- averse institutional shareholding ratios}

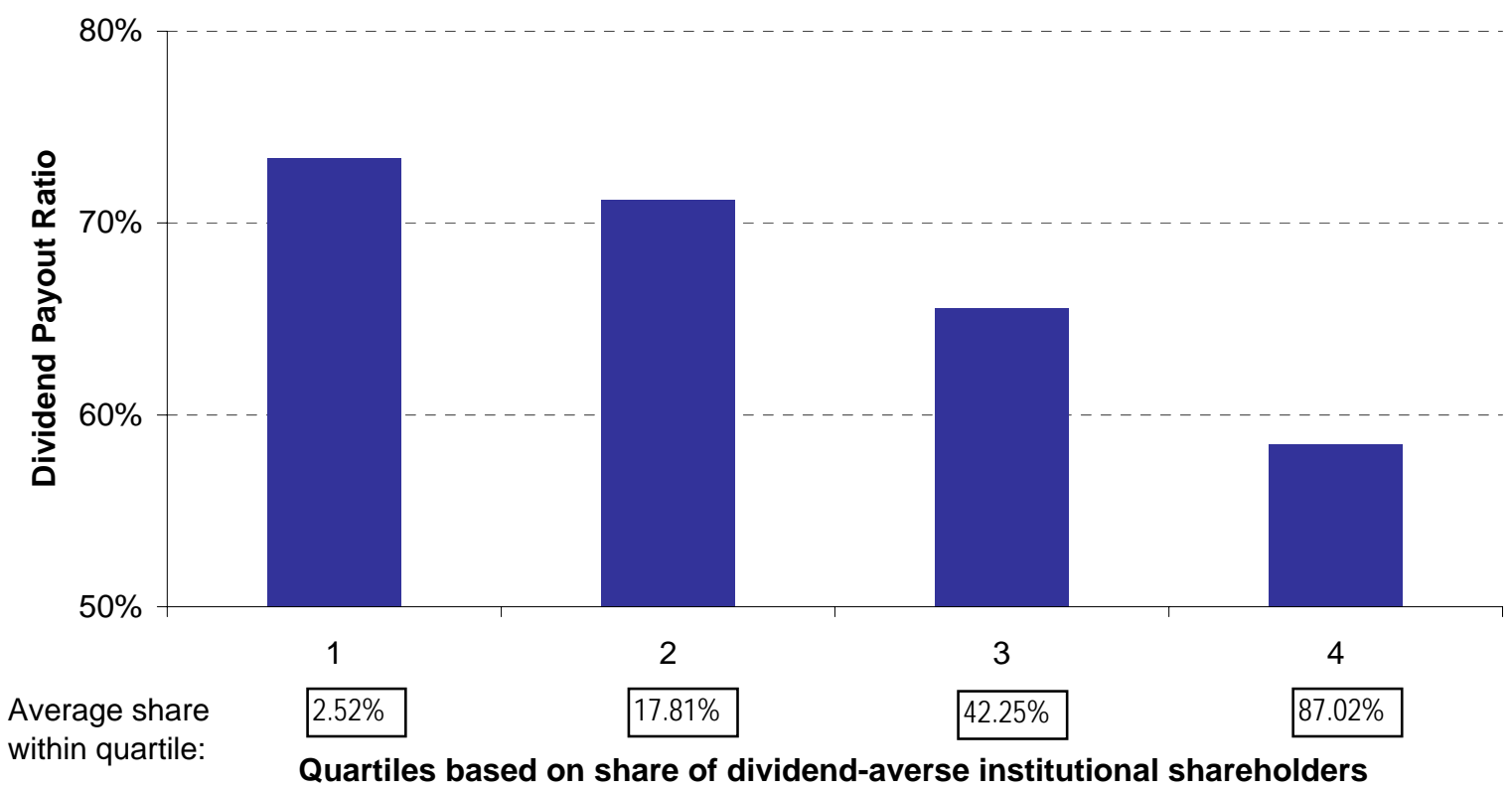

Note: The bars present the average dividend payout ratio across quartiles sorted on the basis of the share of dividend averse institutional shareholders. The average share of dividend-averse institutional shareholders is presented below each quartile number. The quartiles are sorted within a year and then aggregated across years. 
Table 1: Summary statistics

\begin{tabular}{|c|c|c|c|c|c|c|c|c|}
\hline Variable & $\begin{array}{c}\text { Number of } \\
\text { observations }\end{array}$ & Mean & $\begin{array}{c}\text { Standard } \\
\text { Deviation } \\
\end{array}$ & $\begin{array}{c}1 \text { st } \\
\text { percentile }\end{array}$ & $\begin{array}{c}25 \text { th } \\
\text { percentile }\end{array}$ & median & $\begin{array}{c}\text { 75th } \\
\text { percentile }\end{array}$ & $\begin{array}{c}\text { 99th } \\
\text { percentile }\end{array}$ \\
\hline Dividend payout ratio & 76,642 & 0.68 & 0.40 & - & 0.32 & 0.91 & 1.00 & 1.00 \\
\hline Return on assets (ROA) & 76,642 & 0.15 & 0.15 & $(0.08)$ & 0.10 & 0.15 & 0.20 & 0.40 \\
\hline Earnings & 76,642 & 98.96 & 373.58 & $(118.25)$ & 4.42 & 16.71 & 63.52 & $1,608.48$ \\
\hline Market capitalization & 76,642 & $1,779.49$ & $6,645.62$ & 9.75 & 94.93 & 294.16 & $1,083.16$ & $26,247.20$ \\
\hline Ratio of capital expenditures to assets & 76,642 & 0.07 & 0.06 & - & 0.03 & 0.06 & 0.09 & 0.30 \\
\hline Market to book ratio & 76,642 & 1.12 & 1.69 & 0.08 & 0.47 & 0.78 & 1.33 & 5.42 \\
\hline Ln (Sales) & 76,642 & 4.46 & 2.43 & 1.50 & 2.95 & 4.47 & 6.05 & 9.93 \\
\hline
\end{tabular}

Note: Repurchase is the expenditure on the purchase of common and preferred stocks (Item \#115) minus reduction in the value of the preferred shares outstanding (Item \#56). Common dividends is the dollar dividends declared during the fiscal year (Item \#21). Dividend payout ratio is dividend/(dividend + repurchase). Return on asset (ROA) is operating income (Item \#13) / book value of total assets (Item \#6). ROA standard deviation is the standard deviation of the ratio of operating income to total assets measured over the 5-year period from year -4 through 0 . Earnings is defined as earnings after interest and tax (Item \#18). Market capitalization is Item \#24 * Item \#25. Ratio of capital expenditure to assets is the capital expenditure (Item \# 128) divided by total assets (Item \#6). Market to book is book value of total assets (Item \#6) plus market capitalization minus book value of equity (Item \#216)), divided by book value of total assets. Ratio of debt to asset is (book value of total assets (Item \#6) - book value of equity (Item \#216)) / book value of total assets (Item \#6). Ratio of cash to assets is the cash and short-term Investments (Item \#1) divided by total assets. Ln(Sales) is the natural log of sales (Item \#12). 
Table 2: The Relationship between Dividend Payout Ratios and the Proportion of Dividend Averse Institutional Investors

\begin{tabular}{|c|c|c|c|c|c|c|c|c|}
\hline \multirow[b]{4}{*}{ Intercept } & \multicolumn{8}{|c|}{ Dependent Variable: Dividend Payout Ratio } \\
\hline & $(1)$ & $(2)$ & (3) & (4) & $(5)$ & (6) & (7) & $(8)$ \\
\hline & \multicolumn{4}{|c|}{ OLS } & \multicolumn{4}{|c|}{ Fama-Macbeth } \\
\hline & $\begin{array}{r}0.71 \\
(32.78)\end{array}$ & $\begin{array}{r}0.67 \\
(62.94)\end{array}$ & $\begin{array}{r}0.64 \\
(31.18)\end{array}$ & $\begin{array}{r}0.67 \\
(32.72)\end{array}$ & $\begin{array}{r}0.62 \\
(31.78)\end{array}$ & $\begin{array}{r}0.68 \\
(31.58)\end{array}$ & $\begin{array}{r}0.67 \\
(27.25)\end{array}$ & $\begin{array}{r}0.69 \\
(31.82)\end{array}$ \\
\hline $\begin{array}{l}\text { Share of dividend-averse } \\
\text { institutional shareholders }\end{array}$ & $\begin{array}{r}-0.11 \\
(23.23)\end{array}$ & $\begin{array}{r}-0.10 \\
(22.05)\end{array}$ & $\begin{array}{r}-0.10 \\
(22.52)\end{array}$ & $\begin{array}{r}-0.10 \\
(22.89)\end{array}$ & $\begin{array}{r}-0.09 \\
(6.68)\end{array}$ & $\begin{array}{r}-0.08 \\
(7.31)\end{array}$ & $\begin{array}{r}-0.09 \\
(16.56)\end{array}$ & $\begin{array}{r}-0.08 \\
(16.56)\end{array}$ \\
\hline Return on assets (ROA) & & $\begin{array}{r}0.29 \\
(18.47)\end{array}$ & & $\begin{array}{r}0.38 \\
(24.17)\end{array}$ & & $\begin{array}{r}0.27 \\
(7.90)\end{array}$ & & $\begin{array}{r}0.30 \\
(14.69)\end{array}$ \\
\hline ROA standard deviation & & $\begin{array}{r}-1.50 \\
(45.48)\end{array}$ & & $\begin{array}{r}-1.21 \\
(36.21)\end{array}$ & & $\begin{array}{r}-1.50 \\
(5.06)\end{array}$ & & $\begin{array}{r}-1.29 \\
(17.36)\end{array}$ \\
\hline Earnings & & $\begin{array}{r}0.00 \\
(4.26)\end{array}$ & & $\begin{array}{r}0.00 \\
(4.52)\end{array}$ & & $\begin{array}{r}0.00 \\
(2.55)\end{array}$ & & $\begin{array}{r}0.00 \\
(9.17)\end{array}$ \\
\hline Market capitalization & & $\begin{array}{r}0.00 \\
(3.94)\end{array}$ & & $\begin{array}{r}0.00 \\
(3.21)\end{array}$ & & $\begin{array}{r}0.00 \\
(2.28)\end{array}$ & & $\begin{array}{r}0.00 \\
(8.74)\end{array}$ \\
\hline $\begin{array}{l}\text { Ratio of capital } \\
\text { expenditures to assets }\end{array}$ & & $\begin{array}{r}0.01 \\
(0.24)\end{array}$ & & $\begin{array}{r}0.18 \\
(7.03)\end{array}$ & & $\begin{array}{r}0.04 \\
(1.00)\end{array}$ & & $\begin{array}{r}0.07 \\
(3.84)\end{array}$ \\
\hline Market to book ratio & & $\begin{array}{r}0.00 \\
(2.08)\end{array}$ & & $\begin{array}{r}-0.02 \\
(12.05)\end{array}$ & & $\begin{array}{r}0.00 \\
(0.22)\end{array}$ & & $\begin{array}{r}-0.01 \\
(3.80)\end{array}$ \\
\hline Ratio of debt to assets & & $\begin{array}{r}0.05 \\
(5.97)\end{array}$ & & $\begin{array}{r}-0.11 \\
(11.37)\end{array}$ & & $\begin{array}{r}0.03 \\
(0.36)\end{array}$ & & $\begin{array}{r}-0.10 \\
(5.77)\end{array}$ \\
\hline $\begin{array}{l}\text { Year Fixed Effects? } \\
\text { Industry Fixed Effects? }\end{array}$ & $\begin{array}{l}\mathrm{Y} \\
\mathrm{N}\end{array}$ & $\begin{array}{l}\mathrm{Y} \\
\mathrm{N}\end{array}$ & $\begin{array}{l}\mathrm{Y} \\
\mathrm{Y}\end{array}$ & $\begin{array}{l}\mathrm{Y} \\
\mathrm{Y}\end{array}$ & $\begin{array}{l}\mathrm{N} \\
\mathrm{N}\end{array}$ & $\begin{array}{l}\mathrm{N} \\
\mathrm{N}\end{array}$ & $\begin{array}{l}\mathrm{N} \\
\mathrm{Y}\end{array}$ & $\begin{array}{l}\mathrm{N} \\
\mathrm{Y}\end{array}$ \\
\hline Adjusted R-squared & 0.02 & 0.09 & 0.08 & 0.15 & 0.01 & 0.09 & 0.08 & 0.16 \\
\hline Number of observation & 76,642 & 76,642 & 76,642 & 76,642 & 76,642 & 76,642 & 76,642 & 76,642 \\
\hline
\end{tabular}

Note: The dependent variable in these regressions is the ratio of dividends to the sum of dividends and repurchases. Columns 1 through 4 are OLS specifications with t-statistcs based on standard errors clustered at the industry level. Columns 5 through 8 are Fama-MacBeth regressions, with the resulting standard deviations further adjusted for potential autocorrelation in the time-series coefficient estimate, by adopting the method in Pontiff (1996) using AR(1) error terms. t-statistics are below the coefficient estimates. ROA is the ratio of operating income to total assets. ROA standard deviation is the standard deviation of ROA for the five years prior to the firm-year observation. Earnings is defined as earnings after interest and tax. Market capitalization is the market value of common shares outstanding. Ratio of capital expenditures to assets is the ratio of capital expenditures to total assets. Market to book ratio is the ratio of market value of equity to book value of equity. Ratio of debt to assets is the ratio of book debt to book assets. 


\section{Table 3: Robustness of Relationship between Dividend Aversion of Institutional Shareholders and Payout Policy to Different Inclusion Criteria}

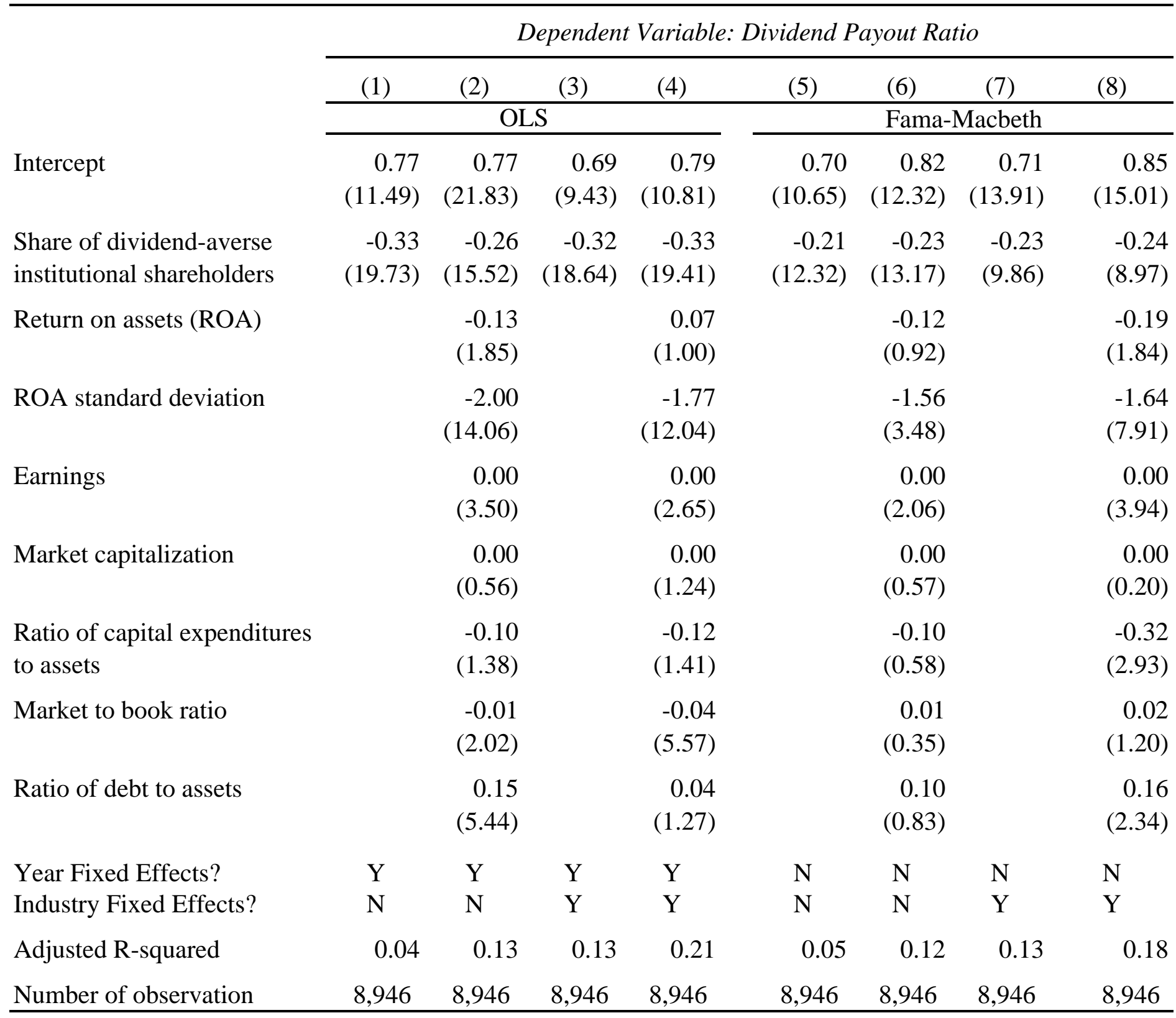

Note: The dependent variable in these regressions is the ratio of dividends to the sum of dividends and repurchases. Columns 1 through 4 are OLS specifications with t-statistcs based on standard errors clustered at the industry level. Columns 5 through 8 are Fama-MacBeth regressions, with the resulting standard deviations further adjusted for potential autocorrelation in the time-series coefficient estimate, by adopting the method in Pontiff (1996) using AR(1) error terms. t-statistics are below the coefficient estimates. ROA is the ratio of operating income to total assets. ROA standard deviation is the standard deviation of ROA for the five years prior to the firm-year observation. Earnings is defined as earnings after interest and tax. Market capitalization is the market value of common shares outstanding. Ratio of capital expenditures to assets is the ratio of capital expenditures to total assets. Market to book ratio is the ratio of market value of equity to book value of equity. Ratio of debt to assets is the ratio of book debt to book assets. 


\section{Table 4: First Stage Results for Determinants of Dividend Payout Policy}

\begin{tabular}{lccr}
\hline & \multicolumn{3}{c}{ Dependent Variable: Dividend Payout Ratio } \\
\cline { 2 - 4 } & \multicolumn{1}{c}{$(1)$} & $(2)$ & $(3)$ \\
\cline { 2 - 4 } Intercept & 0.73 & 0.73 & 0.76 \\
& $(404.15)$ & $(391.79)$ & $(377.10)$ \\
ROA standard deviation & & -1.30 & -0.93 \\
& & $(42.48)$ & $(29.08)$ \\
Ratio of cash to assets & & & -0.41 \\
& -0.51 & & $(36.90)$ \\
Number of observations & $(48.02)$ & & 76,642 \\
Adjusted R-squared & 76,642 & 76,642 & 0.04
\end{tabular}

Note: The dependent variable in these regressions is the ratio of dividends to the sum of dividends and repurchases. ROA standard deviation is the standard deviation of ROA for the five years prior to the firm-year observation. Ratio of cash to assets is the ratio of cash to total assets. t-statistics based on standard errors clustered at the industry level are below the coefficient estimates. 
Table 5: Second Stage Results for Effects of Changes of Dividend Payout Policy on Insitutional Shareholder Bases

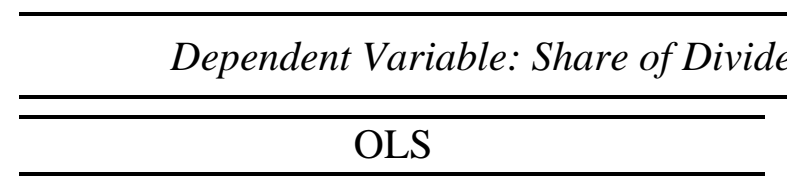

(3)

(4)
(1)

(2)

0.49
$(47.72)$

-3.36
$(7.07)$

(7.07)

0.49

(24.37)

$-3.78$

(7.97)

Market capitalization

Ratio of capital

expenditures to assets

Market to book ratio

Ratio of debt to assets

Year Fixed Effects?

Industry Fixed Effects?

Adjusted R-squared

Number of observations
(12.89)

$-0.18$

(10.86)

0.00

(36.63)

$-0.03$

(1.68)

0.00

(4.94)

0.04

(4.87)

$\begin{array}{ll}\mathrm{Y} & \mathrm{Y} \\ \mathrm{N} & \mathrm{N}\end{array}$

$\mathrm{Y}$
$\mathrm{N}$

0.01

76,642

76,642 $\begin{array}{lll}0.03 & 0.04 & 0.06\end{array}$
$-0.20$

(12.43)

$-0.17$

(10.49)

0.00

(33.39)

0.09

(4.20)

0.00

0.01

76,642

76,642
$\mathrm{Y}$

Y
Fama-Macbeth

(5)

(6)

(7)

(8)

$\begin{array}{rrrr}0.67 & -2.97 & 0.55 & -2.05 \\ (15.46) & (2.70) & (22.43) & (6.64)\end{array}$

$\begin{array}{lll}-0.18 & -0.19 & -0.15 \\ (5.30) & (6.81) & (8.85)\end{array}$

$-0.19$

0.00

(9.41)

$-0.03$

(0.96)

0.00

(4.80)

0.04

(2.60)

0.03

1.21

0.00

0.00

Note: The dependent variable in these regressions is the the ratio of identifiable dividend-averse institutional holdings to the sum of identifiable dividend-averse and non-dividend-averse institutional holdings. Columns 1 through 4 are OLS specifications with t-statistcs based on standard errors clustered at the industry level. Columns 5 through 8 are Fama-MacBeth regressions, with the resulting standard deviations further adjusted for potential autocorrelation in the time-series coefficient estimate, by adopting the method in Pontiff (1996) using AR(1) error terms. t-statistics are below the coefficient estimates. ROA is the ratio of operating income to total assets. ROA standard deviation is the standard deviation of ROA for the five years prior to the firm-year observation. Earnings is defined as earnings after interest and tax. Market capitalization is the market value of common shares outstanding. Ratio of capital expenditures to assets is the ratio of capital expenditures to total assets. Market to book ratio is the ratio of market value of equity to book value of equity. Ratio of debt to assets is the ratio of book debt to book assets. 
Table 6: The Effect of Tax Changes on Dividend Payout Policy

\begin{tabular}{|c|c|c|c|c|}
\hline & \multicolumn{2}{|c|}{$\begin{array}{l}\text { Regression without } \\
\text { industry fixed effects } \\
\end{array}$} & \multicolumn{2}{|c|}{$\begin{array}{c}\text { Regression with } \\
\text { industry fixed effects }\end{array}$} \\
\hline & $(1)$ & $(2)$ & $(3)$ & $(4)$ \\
\hline Change in log of sales & $\begin{array}{r}0.02 \\
(0.13)\end{array}$ & $\begin{array}{r}0.08 \\
(0.13)\end{array}$ & $\begin{array}{r}0.09 \\
(0.13)\end{array}$ & $\begin{array}{r}0.15 \\
(0.13)\end{array}$ \\
\hline $\begin{array}{l}\text { Change in log of weighted average tax } \\
\text { preference for dividend }\end{array}$ & $\begin{array}{r}0.24 \\
(0.19)\end{array}$ & $\begin{array}{r}0.23 \\
(0.19)\end{array}$ & $\begin{array}{r}0.15 \\
(0.19)\end{array}$ & $\begin{array}{r}0.14 \\
(0.19)\end{array}$ \\
\hline Log of lagged dividend payout ratio & $\begin{array}{r}-0.20 \\
(0.01)\end{array}$ & $\begin{array}{r}-0.21 \\
(0.01)\end{array}$ & $\begin{array}{r}-0.21 \\
(0.01)\end{array}$ & $\begin{array}{r}-0.21 \\
(0.01)\end{array}$ \\
\hline Log of lagged sales & $\begin{array}{r}-0.11 \\
(0.02)\end{array}$ & $\begin{array}{r}-0.10 \\
(0.02)\end{array}$ & $\begin{array}{r}-0.10 \\
(0.03)\end{array}$ & $\begin{array}{l}-0.07 \\
(0.03)\end{array}$ \\
\hline Log of lagged investor tax preference & $\begin{array}{r}0.43 \\
(0.12)\end{array}$ & $\begin{array}{r}0.32 \\
(0.12)\end{array}$ & $\begin{array}{r}0.38 \\
(0.13)\end{array}$ & $\begin{array}{r}0.26 \\
(0.13)\end{array}$ \\
\hline Log of lagged theta & & $\begin{array}{r}3.73 \\
(0.51)\end{array}$ & & $\begin{array}{r}3.83 \\
(0.51)\end{array}$ \\
\hline Adjusted R-squared & 0.28 & 0.28 & 0.30 & 0.29 \\
\hline Number of observations & 76,642 & 76,642 & 76,642 & 76,642 \\
\hline $\begin{array}{l}\text { Estimated long-run elasticity of dividend } \\
\text { payout ratio to tax incentives }\end{array}$ & 2.11 & 1.56 & 1.77 & 1.22 \\
\hline
\end{tabular}

Note:The dependent variable is the change of the log of the ratio of dividend payment to the total of dividend and repurchases during a year. The independent variables are change and lagged variables of the log of sales, the change and lagged variables of the log of the tax-preference parameter, the log of lagged overall tax price parameter (Poterba's theta), and the log of lagged ratio of dividend to total payout. The tax-preference parameter is defined as the weighted average value of dividends relative to capital gain for institutional investors as measured by (theta*proportion_dividend_averse_institution + 1*proportion_dividend_neutral_institution). Robust standard errors are reported under each coefficient. 